\title{
Microbial Analysis of Soyabean Milk Sold In Makurdi Metropolis
}

\author{
Liamngee $\mathrm{K}^{1}$., Terna T.P ${ }^{2}$, Bem A.A ${ }^{2}$., Orpin J.B ${ }^{2}$., Mzungu $\mathrm{I}^{2}$., Obaje $\mathrm{M}^{2}$. and \\ Anum, $\mathrm{T}^{3}$ \\ ${ }^{I}$ Department of Biological Sciences, Benue State University, Makurdi, Nigeria. \\ ${ }^{2}$ Department of Biological Sciences, Federal University, Dutsin-Ma, Katsina State, Nigeria. \\ ${ }^{3}$ College of Education, Katsina-Ala, Benue State, Nigeria
}

\begin{abstract}
A survey of the production and consumption rate of soymilk within Makurdi metropolis and its microbial quality was carried out. Samples were collected from women and children who hawked the product in Northbank, Wurukum, Highlevel and Wadata areas of Makurdi. Data on soymilk production and consumption was collected using questionnaire method. Pour plate method and relevant biochemical tests were used for isolation, identification and characterisation of microbes. Proximate analysis was carried out to determine the nutrient content of milk samples. Producer educational status showed that $54.55 \%$ of the producers had primary school qualification while $27.27 \%$ had secondary school certificates; $18.18 \%$ were graduates. The consumption rate showed that $61.79 \%$ were daily consumers, $31.07 \%$ occasional consumers and $7.14 \%$ made up nonconsumers. Proximate chemical analysis showed that the samples had high moisture content ranging from 68.50 $-91.49 \%$ with the ash content being $0.30-0.90 \%$. The fibre content ranged from $0.10 \%-0.35 \%$ and the lipid content, $1.56 \%-17.10 \%$. The protein content ranged from 2.86 to $7.76 \%$ while the carbohydrate content ranged from $3.09-13.93 \%$. The microbial load of soymilk ranged from $6.9 \times 10^{7}-7.6 \times 10^{7}$ c.f.u. $/ \mathrm{ml}$ for North bank, $4.1 \times 10^{7}-5.6 \times 10^{7}$ c.f.u. $/ \mathrm{ml}$ for Wurukum, $3.0 \times 10^{7}-4.7 \times 10^{7}$ c.f.u. $/ \mathrm{ml}$ for High level and $6.0 \times 10^{7}-$ $8.5 \times 10^{7}$ c.f.u. $/ \mathrm{ml}$ for Wadata respectively. All samples were contaminated with members of the enterobacteriaceae, including E. coli, Klebsiella spp, Salmonella typhi, Streptococcus faecalis, and Staphylococcus aureus. Soymilk sold in the sampled areas were highly contaminated with faecal microbes, indicating poor hygiene of handlers and sanitary quality of processing water.
\end{abstract}

Key Words: Biochemical test, Makurdi, microbial load, proximate analysis, soymilk,

\section{Introduction}

Soyabean (Glycine max) is a high-protein legume grown as food for both humans and livestock. Although indigenous to Eastern Asia [1], it is known by different names in different parts of the world; soyabeans (Nigeria), Chinese pea (China), Churiabean (Manchuria) [2].

The use of soyabeans is traced back to the orient where it was consumed in form of fermented foods. Today, its uses range from the preparation of tofu, tempeh and natto, to the fortification and enrichment of foods such as in soy fortified wheat bread and coy soy blends, soy sauces, soy yoghurt and soy cream cheese [3; 4]. Soyabeans, which has been cultivated and considered as a miracle bean by many people, is the main source of protein for all of East Asia, particularly to vegetarians. In Nigeria, although the cultivation of soyabeans has been successfully established, a greater percentage of the whole produce until now had been cultivated and exported as cash crop. Presently, soyabeans is incorporated into so many food formulation of both children and adults to enhance nutritional value of foods [5], in preparations such as "dawadawa", allele, moi-moi, akara, soy-ogi and most recently as soymilk [1]. Other commercial uses in animal feed production and the vegetable oil industry cannot be overemphasized [6].

In addition to poor handling and unhygienic practices of local producers of soymilk products, the nutrient composition of soymilk milk makes it an excellent bacteriological medium [5]. These have been implicated in the occurrence and prevalence rate of diseases such as typhoid fever and dysentery among soymilk consumers $[7 ; 8]$.

The sale of soymilk is quite popular in Makurdi, but there is no report on its microbiological quality, which should have addressed the safety of its consumers in Makurdi. This study was therefore aimed at evaluating the microbial load and nutritive value of soymilk as a means of addressing the safety concerns of its consumers in the study area.

\section{Materials and Methods}

\subsection{Survey of Soymilk Production and Consumption}

The study was carried out in Wurukum, Wadata, North Bank and High Level areas of Makurdi, Benue State. A questionnaire was designed to collect data on soymilk production and consumption. A total of 280 questionnaires were given out to men, women, students, house wives, civil servants and children in the survey 
areas. Data collected included Gender of respondents, Age of consumers, Educational status of producers, Occupation of respondents and Consumption rate.

\subsection{Collection of Soymilk Samples}

The soymilk samples which were already packaged in polyethylene sachets or plastic bottles were collected from women and children that hawk the product round Makurdi and taken to the Microbiology laboratory of the Department of Biological Sciences, Benue State University, Makurdi, and preserved at $4{ }^{\circ} \mathrm{C}$ for further analysis.

\subsection{Microbial Analysis of Soymilk Samples}

\subsubsection{Inoculation of Samples}

The pour plate method of Downes and Ito [9] was used. Plate count agar (Biotech) was used for total aerobic counts. Eosin Methylene Blue Agar (Biotech) was the choice for isolation of coliforms. Whereas Nutrient and MacConkey agar were used for other bacteria. Incubation was in an aerobic incubator (Nino/30/CLAD) for 24 hours at $37^{\circ} \mathrm{C}$. After 24 hours, the bacteria colonies that appeared on plates were counted using a digital colony counter (Digincont 02236 ). The average colony counts from duplicate plates were obtained and expressed as colony forming units (c.f.u.) per millilitre of sample.

\subsubsection{Isolation}

All pure cultures of bacteria isolated were maintained on appropriate agar slants. The isolates were kept in the refrigerator $\left(4-8^{\circ} \mathrm{C}\right)$ prior to identification. Cultural characteristics of discrete colonies such as colour, shape elevation, pigmentation, opacity and nature of edges of the colonies were observed and noted.

\subsubsection{Characterization of Isolates}

i) Catalase test

A small amount of pure bacterial growth from appropriate agar slant was transferred to the surface of a clean glass slide with a sterile wire loop. A few drops of $3 \%$ hydrogen peroxide $\left(\mathrm{H}_{2} \mathrm{O}_{2}\right)$ were immediately added, and observed for any evolvement of gas.

ii) Oxidase test

The method reported by Gaffa and Azoro [10] was used. A freshly prepared 1\% solution of tetra-methyl-pphenylene-diamine dihydrochloride was poured onto the culture of the test bacteria on the plate so as to cover the surface. This was then decanted and observed for either rapid or non development of purple colour.

iii) Lactose fermentation test

Lactose broth was dispensed in $9 \mathrm{ml}$ amounts into test tubes containing inverted Durham's tubes. The tubes were further autoclaved at $121^{\circ} \mathrm{C}$ for 10 minutes at $15 \mathrm{lb}$ pressure. Each tube was then inoculated with $1 \mathrm{ml}$ of soymilk sample and incubated at $37^{\circ} \mathrm{C}$ for $18-24$ hours. Tubes were examined for any changes in colour and presence of gas.

\section{iv) Slide agglutination test}

The method reported by Gaffa and Azoro [10] was used. A drop of sterile water was placed on a clean slide and a small amount of the test organism emulsified in the fluid on the slide to form a smooth milky suspension. Using an inoculating wire loop, a small portion of undiluted plasma preserved at room temperature was placed on the bacterial suspension on the slide. The slide was observed for coarse agglutination within five to ten minutes. A slower reaction meant a negative result.

\section{v) Motility test}

This was carried out using the procedure outlined by Gaffa and Azoro [10]. A thin layer of Vaseline was applied around the edge of the well in a concave slide. A loopful of the bacterial suspension was put in the centre of a cover slip. The concave slide was inverted and pressed on top of the cover slip so that the cover slip completely covered the well. The preparation was quickly turned right side up again. The edges of the cover slip were checked to ensure that the vaseline sealed the edges properly. Bacterial suspension on the underside of the cover slip was observed under the microscope for bacterial cells in motion.

\section{vi) Spore test}

A thin film of the bacteria culture was made, dried and heat fixed with a minimal amount of heat. The film was then stained with Zeihl Neelsen's carbol fuchsin for 3-5 minutes. The preparation was heated until steam was observed. The stain was washed in water and treated with $0.5 \%$ of $\mathrm{H}_{2} \mathrm{SO}_{4}$ for few minutes. The preparation was decolorized by dipping the slide in a $2 \%$ solution of nitric acid in absolute ethyl alcohol and 
immediately washed off in water. The counter stain, aqueous methylene blue was applied and left for about 3 minutes. The preparation was washed in water, dried and viewed under the microscope for possible presence of spores.

\section{v) Tests for coliforms}

$\mathrm{v}$ (a). Presumptive test

$1 \mathrm{ml}$ of thoroughly mixed soymilk samples were inoculated into lactose broth tubes containing $9 \mathrm{mls}$ of the media. The tubes were incubated at $37^{\circ} \mathrm{C}$ and observed after 24 hours for any evidence of gas production.

$\mathrm{v}$ (b). The confirmed test

Samples showing positive lactose fermentation were transferred into Eosin Methylene Blue Agar (EMBA) on plates using sterilized wire loop and incubated for 24 hours at $37^{\circ} \mathrm{C}$. Growth was monitored for the either the presence (metallic sheen) or absence of coliforms (colourless colonies).

$\mathrm{v}$ (c). The completed test

Organisms showing dark and pinkish mucoid colonies were inoculated into lactose broth. The production of gas in lactose broth was considered as evidence of coliforms, while microscopic identification of Gram negative, non-sporing short bacilli showed a positive completed test.

\subsection{Proximate analysis of soymilk}

\subsubsection{Determination of moisture content in soymilk}

The method of Pearson [11] was used. The weight of an empty aluminium dish can $\left(\mathrm{W}_{0}\right)$ was determined before the sample was introduced into it. About $20 \mathrm{mls}$ of the soymilk sample was measured out and further weighed $\left(\mathrm{W}_{1}\right)$ in the aluminium dish can. The aluminium dish can was then dried in a hot air oven for 24 hours and cooled in a dessicator and weight $\left(\mathrm{W}_{2}\right)$ measureded. Percentage of moisture content was determined as follows:

Percentage of moisture content $=\frac{(\mathrm{W} 1-\mathrm{W} 0)-(\mathrm{W} 2-\mathrm{W} 0)}{(\mathrm{W} 1-\mathrm{W} 0)} \times 100$

Where: $\mathrm{W} 0=$ Weight of empty moisture can

$\mathrm{W} 1=$ Weight of moisture can and sample

$\mathrm{W} 2=$ Weight of dessicated sample

$(\mathrm{W} 1-\mathrm{W} 0)-(\mathrm{W} 2-\mathrm{W} 0)=$ Weight loss

$(\mathrm{W} 1-\mathrm{W} 0)=$ Weight of sample

\subsubsection{Determination of ash content in soymilk}

The method reported by AOAC [12] was used. An empty clean crucible dish was weighed and the weight noted as W0. Soymilk sample in $2 \mathrm{ml}$ amount was measured and weighed in the empty clean crucible; the weight (W1) was noted. The crucible containing the sample was further placed in a muffle furnace and ashed at $500^{\circ} \mathrm{C}-600^{\circ} \mathrm{C}$ for 3 hours. The crucible was removed from the muffle furnace and cooled in a dessicator, and weighed (W2) using a weighing balance. Percentage ash content was determined as follows:

Percentage of ash content $=\frac{(\mathrm{W} 2-\mathrm{W} 0)}{(\mathrm{W} 1-\mathrm{W} 0)} \times 100$

Where: $\mathrm{W} 0=$ Weight of empty crucible

$\mathrm{W} 1=$ Weight of sample and crucible

$\mathrm{W} 2=$ Weight of ash and crucible

\subsubsection{Determination of crude fibre content in soymilk}

The method reported by AOAC [12] was used. 20mls of soymilk sample were weighed in a 1 litre conical flask and the weight (W0) noted. $200 \mathrm{mls}$ of boiling $1.25 \% \mathrm{H}_{2} \mathrm{SO}_{4}$ were added into the conical flask containing the sample and boiled gently for 30minutes. The content was filtered through a muslin cloth and the residue scraped into a clean conical flask using a spatula. $20 \mathrm{mls}$ of boiling $1.25 \% \mathrm{NaOH}$ were added and allowed to boil gently for 30 minutes. Further filtration was done using using the buckner pressurized filter through a muslin cloth spread over its funnel. The resulting residue was thoroughly washed with distilled water and rinsed once with $10 \% \mathrm{HCl}$ and twice with ethanol. Final rinsing with petroleum ether was done thrice and allowed to drain. The residue was scraped into a flat silica dish and dried overnight in the oven at $105^{\circ} \mathrm{C}$. Afterwards, it was cooled in the dessicator and the sample weighed (W1). The sample was further ashed at $55^{\circ} \mathrm{C}$ for 90 minutes in a muffle furnace, cooled again in the dessicator and reweighed. Percentage fibre content was determined as follows:

Percentage fibre content $=\frac{(\mathrm{W} 1-\mathrm{W} 2)}{\mathrm{W} 0} \times 100$

Where: $\mathrm{W} 0=$ Weight of sample

$\mathrm{W} 1=$ Weight of insoluble material 
$\mathrm{W} 2=$ Weight of ash

\subsubsection{Determination of lipid content in soymilk}

The method reported by AOAC [12] was used. A $250 \mathrm{ml}$ round bottom flask was dried in an oven, allowed to cool in the dessicator and the weight measured. $200 \mathrm{ml}$ of petroleum ether were introduced into the dry $250 \mathrm{ml}$ round bottom flask. $10 \mathrm{mls}$ of the sample were measured using a measuring cylinder and weighed in a labelled porous thimble, which was covered with a clean white cotton wool. The covered thimble was placed into the soxhlet extractor (Model: EME 60250/CE) fitted into the round bottomed flask. The extraction apparatus was set up with the flask on the hot water bath of the soxhlet extracting unit. The content of the round bottom flask was then heated. As the ether evaporated, it condensed dropped into the thimble where it extracted the ether soluble constituent into the round-bottomed flask. The extraction lasted for 5-6 hours during which all the petroleum ether moved up to the extractor, leaving behind the fats in the round bottom flask. The porous thimble was removed with care and the petroleum ether collected from the top for re-use. The round-bottomed flask containing the lipids was then removed and oven dried for 1 hour at $105-110^{\circ} \mathrm{C}$. After drying, it was further transferred into a dessicator (containing silica gel) where it was cooled and also weighed.

Percentage of lipid content $=\frac{(\mathrm{W} 3-\mathrm{W} 2)}{\mathrm{W} 1-\mathrm{W} 0} \times 100$

Where: $\mathrm{W} 0=$ Weight of empty porous thimble

$\mathrm{W} 1=$ Weight of thimble and sample

$\mathrm{W} 2=$ Weight of empty extraction flask

$\mathrm{W} 3=$ Weight of extraction flask and extract

$\mathrm{W} 1-\mathrm{W} 0=$ Weight of sample

$\mathrm{W} 2-\mathrm{W} 3=$ Weight of extract

\subsubsection{Determination of protein content in soymilk}

The soymilk sample was measured in $5 \mathrm{ml}$ amounts in a measuring cylinder and introduced into a $100 \mathrm{ml}$ micro kjeidahl nitrogen digestion flask. The following were further added to the flask: $5 \mathrm{mls}$ of distilled water, one tablet of mercury kjeidahl catalyst, half spatula full of $\mathrm{K}_{2} \mathrm{SO}_{4}$, $5 \mathrm{mls}$ of concentrated $\mathrm{H}_{2} \mathrm{SO}_{4}$

The flask was placed on a 6 - unit digester (model: 65500) inside the fume cupboard and digested for 3 hours. After the digestion was completed, the content was cooled; leaving behind a colourless residue. Some quantity of distilled water was added to the colourless digest and the flask swirled until everything was dissolved. The content was emptied into a $100 \mathrm{ml}$ volumetric flask.

The Malkam distillation apparatus was set up and nitrogen distillation carried out as follows: $5 \mathrm{ml}$ of the extract were pipetted into the distillation pot, followed by $5 \mathrm{ml}$ of $55 \% \mathrm{NaOH}$ and distillation carried out for 15 minutes. During the distillation, a $100 \mathrm{~m} /$ conical flask containing $5 \mathrm{ml}$ boric acid was kept under the condenser to collect the distillate. Boric acid was observed for any change in colour.

\subsubsection{Titration}

The method reported by AOAC [12] was used. A $50 \mathrm{ml}$ burette was filled with $0.01 \mathrm{~N} \mathrm{HCl}$ and titrated against the ammonia distillate until colour change was observed. The second burette reading was also noted and titre value calculated. Percentage of protein content was determined as follows:

Percentage of protein content $=\frac{0.014 \times \text { vol. of titre } \times \mathrm{NHCl} \times \text { vol. of extract }}{\text { Weight of Sample }} \times 100$

Where: $0.014=$ nitrogen factor

Vol. of titre $=$ Volume read from burette

$\mathrm{NHCl}=$ Normality of $\mathrm{HCl}$ acid used

Vol. of extract $=$ Capacity of the volumetric flask

$100=$ A constant

\subsubsection{Determination of carbohydrate content in soymilk}

The method of Obsorne and Voogt [13] was used. Carbohydrate content was determined indirectly by subtracting the crude protein, crude fibre, crude lipid, ash and moisture content from $100 \%$ as follows: Percentage carbohydrate content $(\%$ CC $)=100-(\%$ Protein $+\%$ Fibre $+\%$ Ash $+\%$ Moisture $+\%$ Lipid $)$

\subsection{Soymilk production and consumption in Makurdi}

\section{Results}

The demographic characteristics of respondents on soymilk production and consumption in Makurdi metropolis are presented in TABLE $1.73 .57 \%$ of respondents were males while $26.43 \%$ were females. The highest number of respondents (28.46\%) was aged between 26 - 30 years, followed by age group 31-35 (25.00\%). Persons above 40 years of age represented the least number of respondents $(4.61 \%)$. All producers of 
soymilk in the study were female and educated. $54.55 \%$ of producers had primary education, while $27.27 \%$ had secondary education. Only $7.14 \%$ of producers were graduates. $33.57 \%$ of producers (majority) were mainly house wives. $61.79 \%$ of respondents were daily consumers, $31.07 \%$ occasional consumers and $7.14 \%$ nonconsumers.

TABLE 1: Demographic characteristics of respondents on soymilk production and consumption in Makurdi metropolis

\begin{tabular}{lll} 
Demographic characteristics & Number of Respondents & Percentage (\%) \\
\hline Gender & 206 & 73.57 \\
Males & 74 & 26.43 \\
Females & 280 & 100 \\
Total & & \\
Age (years) of consumers & 15 & 5.77 \\
Below 20 & 58 & 22.31 \\
$21-25$ & 74 & 28.46 \\
$26-30$ & 65 & 25.00 \\
$31-35$ & 36 & 13.85 \\
$36-40$ & 12 & 4.61 \\
Above 40 & & \\
Sex of producers & 0 & 0.00 \\
Male & 11 & 100 \\
Female & & \\
Educational status of producers & - & - \\
No School & 6 & 54.55 \\
Primary School & 3 & 27.27 \\
Secondary School & 2 & 18.18 \\
Graduates & & \\
Consumption rate & 173 & 61.79 \\
Daily consumers & 87 & 31.07 \\
Occasional consumers & 20 & 7.14 \\
Non - Consumers & 46 & 16.43 \\
Occupation of respondents & 94 & 33.57 \\
Civil servants & 63 & 22.50 \\
Housewives & 77 & 27.50 \\
Students & & \\
Self - employed individuals & & \\
\hline
\end{tabular}

\subsection{Microbial load of soymilk sold in Makurdi metropolis}

The microbial load of soymilk sold in Makurdi metropolis is presented in TABLE 2a. The highest microbial load $\left(8.5 \times 10^{7}\right.$ c.f.u. $\left./ \mathrm{ml}\right)$ was observed in the Wadata area while the least $\left(3.0 \times 10^{7}\right.$ c.f.u. $\left./ \mathrm{ml}\right)$ was at High level. A slight decline in microbial load was noted after the first week of sample collection. Microbial load of soymilk samples was significantly different (TABLE 2 b) across the sampling locations as well as sampling periods $(\mathrm{P}=0.05)$.

Table 2a: Microbial load of soymilk (in c.f.u./ml) sold in Makurdi metropolis

\begin{tabular}{llll}
\hline Location & Week 1 $($ c.f.u./ml) & Week 2 (c.f.u./ml) & Week 3 (c.f.u./ml) \\
\hline North Bank & $7.6 \times 10^{7}$ & $6.9 \times 10^{7}$ & $7.1 \times 10^{7}$ \\
Wurukum & $5.6 \times 10^{7}$ & $4.1 \times 10^{7}$ & $4.5 \times 10^{7}$ \\
High level & $4.7 \times 10^{7}$ & $3.8 \times 10^{7}$ & $3.0 \times 10^{7}$ \\
Wadata & $8.5 \times 10^{7}$ & $6.6 \times 10^{7}$ & $6.0 \times 10^{7}$ \\
\hline
\end{tabular}

TABLE 2b: Analysis of Variance (ANOVA) for the Microbial Load of Soymilk Sold in Makurdi Metropolis

\begin{tabular}{|c|c|c|c|c|c|c|c|}
\hline $\begin{array}{l}\text { Source } \\
\text { Variation }\end{array}$ & of & $\begin{array}{ll}\text { Degree } & \text { of } \\
\text { Freedom (df) } & \\
\end{array}$ & $\begin{array}{l}\text { Sum of Squares } \\
\text { (SS) }\end{array}$ & $\begin{array}{l}\text { Mean } \\
\text { (MS) }\end{array}$ & Squares & $\begin{array}{l}\mathbf{F}-\text { Calculated } \\
(\mathbf{F}-\text { cal })\end{array}$ & $\begin{array}{l}\text { F - Tabulated } \\
(\mathbf{F}-\text { tab })\end{array}$ \\
\hline Weeks & & 2 & 4.94 & 2.47 & & 10.74 & 5.14 \\
\hline Location & & 3 & 25.34 & 8.45 & & 36.72 & 4.76 \\
\hline Error & & 6 & 1.38 & 0.23 & & & \\
\hline Total & & 11 & 31.66 & & & & \\
\hline
\end{tabular}


$\mathrm{F}-\mathrm{cal}>\mathrm{F}-\mathrm{tab}=$ There is significant difference $(\mathrm{P}=0.05)$

$\mathrm{F}-\mathrm{tab}>\mathrm{F}-\mathrm{cal}=$ No significant difference $(\mathrm{P}=0.05)$

\subsection{Biochemical characteristics of organisms}

Biochemical characterisation of microbes isolated from soymilk samples (TABLE 3) showed that the samples were contaminated with coliforms and other bacterial species. Organisms isolated include Escherichia coli, Klebsiella spp, Salmonella typhi, Streptococcus faecalis, Staphylococcus aureus, Staphylococcus (C-ve), and Aerobacter aerogenes as presented.

TABLE 3: Biochemical Characteristics of Organisms

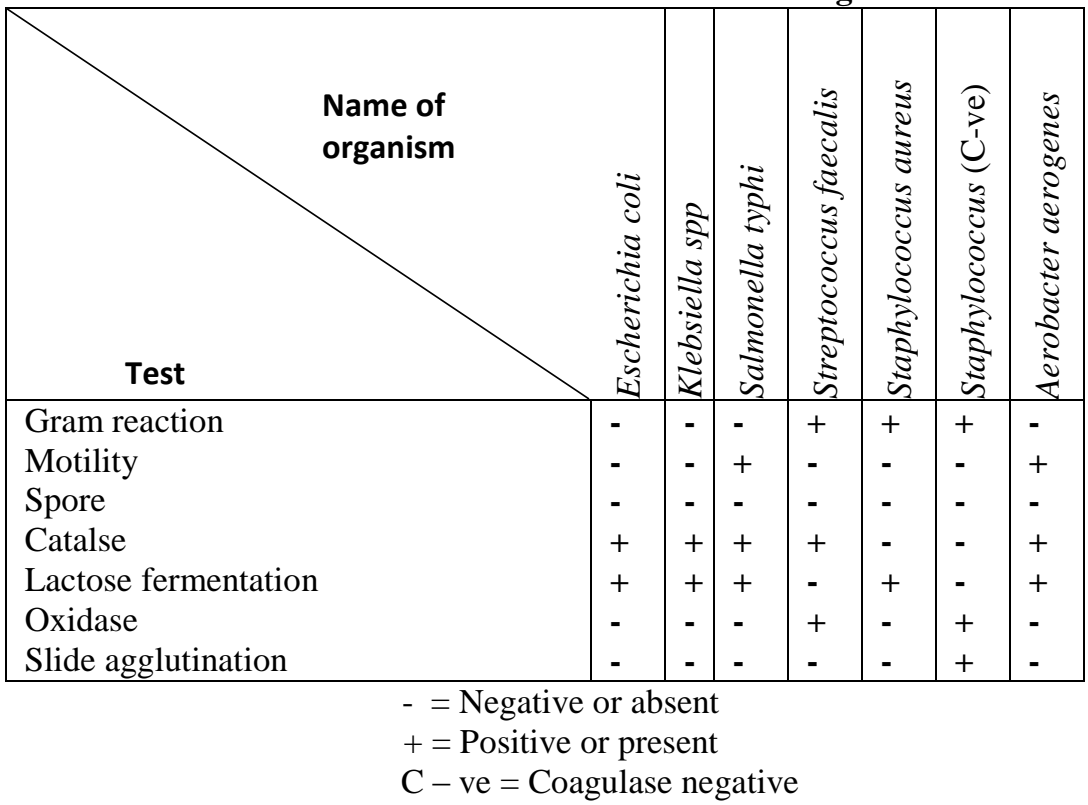

\subsection{Test for coliforms}

The cultural characteristics and results of test for coliforms are presented in TABLE 4. Probable organisms were E. coli, Klebsiella spp, Salmonella spp, Streptococcus faecalis, Staphylococcus aureus, Staphylococcus (Coagulase-ve), and, Aerobacter aerogenes.

TABLE 4: Cultural characteristics and result of test for coiforms

\begin{tabular}{|c|c|c|c|c|}
\hline $\begin{array}{l}\text { Cultural Growth on } \\
\text { Nutrient Agar }\end{array}$ & $\begin{array}{l}\text { Cultural Growth on } \\
\text { MacConkey Agar }\end{array}$ & $\begin{array}{l}\text { Growth } \\
\text { Characteristics on } \\
\text { Eosin Methylene Blue } \\
\text { Agar (EMBA) }\end{array}$ & $\begin{array}{l}\text { Microscopic } \\
\text { Appearance }\end{array}$ & $\begin{array}{l}\text { Probable } \\
\text { Organism }\end{array}$ \\
\hline $\begin{array}{l}\text { Flat, yellow, opaque, } \\
\text { undulate colonies with } \\
\text { slightly deeper } \\
\text { coloured centers about } \\
1.25 \mathrm{~mm} \text { diameter. }\end{array}$ & $\begin{array}{l}\text { Red, opaque, flat } \\
\text { colonies with undulate } \\
\text { edges about } 1.75 \mathrm{~mm} \\
\text { diameter. }\end{array}$ & $\begin{array}{l}\text { Dark almost black } \\
\text { centered undulate } \\
\text { colonies with metallic } \\
\text { sheen about } 1.25 \mathrm{~mm} \\
\text { diameter }\end{array}$ & Single, fat, short rods & E. coli \\
\hline
\end{tabular}

Flat, extremely Red, flat colonies, mucoid, transparent colonies, varying from white to yellow in colour, with rhizoid edges about $1.75 \mathrm{~mm}$ diameter.

Flat, yellow, opaque3 colonies with undulate edges about $0.65 \mathrm{~mm}$ diameter.

Dome shaped yellow opaque colonies with edges crenated about opque with rhizoid edges about $1.75 \mathrm{~mm}$ in diameter colonies with rhizoid edges about $0.75 \mathrm{~mm}$ in diameter.

Raised, red, opaque colonies with undulated edges about
Red, flat, opaque
Single, fat, short rods $\quad$ Klebsiella spp

Single, fat, short rods Salmonella spp

Single chains $\quad$ Streptococcus faecalis 
$0.5 \mathrm{~mm}$ diameter.

Deep yellow, convex papillate, opaque colonies with entire edges about $0.75 \mathrm{~mm}$ diameter.

Yellow, convex paillate opaque colonies with entire edges, about $0.75 \mathrm{~mm}$ diameter
$0.85 \mathrm{~mm}$ diameter
Spherical clusters

Spherical clusters

Staphylococcus (Coagulase-ve)
Staphylococcus aureus

\author{
Flat, purple to pinkish \\ mucoid colonies, opque \\ Single, fat, short rods \\ Aerobacter \\ aerogenes \\ about $0.75 \mathrm{~mm}$ diameter
}

- $\quad$ No growth

\subsection{Proximate composition of soymilk}

The proximate composition of soymilk (TABLE 5) showed that the samples had high moisture content and very low content of fibre and ash. Samples from Wadata had the highest ash (1.00\%), fibre $(0.35 \%)$ and lipid $(18.00 \%)$ contents respectively, while samples from Wurukum, High level and North Bank had the highest moisture $(91.49 \%)$, protein $(7.76 \%)$ and carbohydrate $(13.39 \%)$ contents respectively. Soymilk samples from Wurukum, had the least fibre $(0.10 \%)$, lipid $(1.56 \%)$, protein $(2.86 \%)$ and carbohydrate $(3.09 \%)$ contents respectively. Ash content was least in soymilk samples collected in Northbank $(0.80 \%)$, while moisture content was least in soymilk samples collected in High level (68.50\%).

TABLE 5: Proximate composition of soymilk Percentage Compositon (\%)

\begin{tabular}{lllllll} 
Area Sampled & Moisture & Ash & Fibre & Lipid & Protein & Carbohydrate \\
\hline North Bank & 74.80 & 0.80 & 0.10 & 4.13 & 6.78 & 13.39 \\
Wurukum & 91.49 & 0.90 & 0.10 & 1.56 & 2.86 & 3.09 \\
Highlevel & 68.50 & 0.98 & 0.30 & 17.10 & 7.76 & 5.36 \\
Wadata & 70.26 & 1.00 & 0.35 & 18.00 & 7.00 & 3.39 \\
\hline
\end{tabular}

\subsection{Consumer acceptability of soymilk}

Results for consumer acceptability test of soymilk in the study area (TABLE 6) showed that acceptability of soymilk by consumers ranged from moderate. to extreme

TABLE 6: Consumer acceptability of soymilk acceptability

\section{Scale}

\begin{tabular}{llll} 
North Bank & Wurukum & Highlevel & Wadata \\
\hline 9.0 & 8.0 & 8.0 & 8.4 \\
8.0 & 7.0 & 7.0 & 7.1 \\
8.0 & 6.0 & 7.0 & 7.0 \\
8.0 & 7.0 & 7.0 & 7.0 \\
8.0 & 7.0 & 7.1 & 7.3 \\
\hline
\end{tabular}

\footnotetext{
$9=$ like extremely

$8=$ Like very much

$7=$ Like moderately

$6=$ Like slightly

$5=$ Neither like nor dislike

$$
\begin{aligned}
& 4=\text { Dislike slightly } \\
& 3=\text { Dislike moderately } \\
& 2=\text { Dislike very much } \\
& 1=\text { Dislike extremely }
\end{aligned}
$$
}

\section{Discussion}

Majority of respondents were males; 206(73.57\%) within the ages of 21-30 years. This group represents the most labour active age group in the study area, made up of students, labourers, farmers, bus drivers and other artisans who patronise the product for breakfast in preparation for the day's activities. On the 
other hand, soymilk production in the study area was exclusive to females. This can be explained by the fact in this part of the world, cooking is mostly seen as the sole responsibility of females.

Soymilk on sale in Makurdi is contaminated by various microorganisms such as E. coli, Klebsiella spp, Salmonella typhi, Streptococcus faecalis, Staphylococcus aureus, Staphylococcus (Coagulase negative). This is in agreement with findings of Soomro [14] who reported the presence of Staphylococcus aureus in samples obtained from different locations in India. In a similar work on microorganisms associated with locally processed milk products (nono and Wara) at Ilorin, E. coli, and Staph aureus were also isolated [15]. Streptococcus faecalis was isolated in this study but absent in reports earlier mentioned. This may be attributed to the culture media used and differences in environmental conditions.

The contamination of this soymilk product be members of the Enterobacteriaceae is mostly as a result of poor handling, use of contaminated raw materials, unhygienic processing environment and lack of good manufacturing practices by processors. This is also evidenced by the low literacy level of producers in the study. A similar report has been published by Ismail [16].

Results for proximate analysis of moisture content of Northbank (74.80\%), High level (68.50\%) and Wadata $(70.26 \%)$ were identical to result $(74.50 \%)$ reported by Goodman [17] and the moisture content of Wurukum (91.49\%) close to the value (91.4\%) reported by Asiedu [18]. The fibre content of all soymilk samples in this study areas were however within the range $0.1 \%-0.35 \%$. This was in contrast to $0.00 \%$ reported by Asiedu [18] and Goodman [17]. Moreso, the lipid content (4.13\%) in soymilk from Northbank was same as that $(4.13 \%)$ reported by Goodman [17], while that of Wurukum $(1.56 \%)$ was slightly higher than that $(1.50 \%)$ reported by Asiedu [18]. Those of Highlevel (17.10\%) and Wadata (18.00\%) were slightly lower than the value (19.89\%) reported Habeeb [19].

Differences in nutrient content observed in the study in comparism to others reported by various researchers may be due to differences in soybean varieties used in milk production as well as slight variations in assay techniques used.

\section{Conclusion}

Soymilk which is highly consumed in Makurdi is commonly contaminated with bacteria of faecal origin whose source may be traced to poor hygiene of producers, unsanitary conditions of processing equipment and raw materials. Observation of strict sanitary practices and application of Hazard Analysis Critical Control Points (HACCP) at necessary points will reduce the level of contamination and enhance consumer safety.

\section{References}

[1] J. Dinakin, Soyabean production in Nigeria (London: Academic Press, 1985).

[2] A.H. Keshun, E.H. Marth, and R.H. Turner, Growth and Acidity of Lactic Acid Bacteria in Soymilk, Journal of Clinical Microbiology, 33, 1999, 34-37.

[3] L.R. Crowley, and D.C. Dale, Effect of Heat Treatment of the Nutritive Value of Soymilk Protein Fed to weaning rats. Journal of Food Science, 30, 1975, 723-728.

[4] O.H. Yang, Easy to Prepare Soybean Foods for Villagers. Tropical Foods Chemistry and Nutrition. Vol. 2 (London: Academic Press, 1979).

[5] P.O. Michael, Use of Soyabeans in Treatment of Protein Malnutrition in Infants, Journal of Tropical and Agricultural Research 8, 1986, 7-8.

[6] W.F. Kochlair, Chemical Changes in Food During Processing, IFT Basic Symposium Series (West Port, Connecticut: The AVI Publishing Co. Inc. 1986)

[7] T.V. Alanga, P.C. Beaver, F.A. Goldman, The Standardization of Faecal Smears for Estimating Egg Production and Worm Burden, Journal of Parasitology, 36, 1975, 451- 453.

[8] D. Addo, S.S. Soo, H. Towler, Soymilk: A Comparism of Processing Methods on Yields and of Food Science 8, 1977, 239-243.

[9] F.P. Downes, and K. Ito, Compendium of Methods for Microbiological Examination of Foods (Washington DC, 2001).

[10] T. Gaffa, and C. Azoro, Bacteriology for Biologists, Caterers and Food Technologists, (Kaduna: Amana Printing and Advert Ltd. 2005).

[11] D. Pearson, The Chemical Analysis of Food, $7^{\text {th }}$ Edition (Edinburg, London: Church Hill Living Stones, 1970).

[12] AOAC, Association of Official Analytical Chemists. Official Methods of Analysis, $16^{\text {th }}$ Edition (Virginia, Washington DC. 1980).

[13] P.R. Osborne, and P. Voogt, The Analysis of Nutrients in Foods. London (Academic Press Ltd. 1978).H. Soomro, Isolation of Staphylococcus aureus from Milk Products Sold at Sweetmeat Shops of Hyderabad, India. Journal of Biological Science, 31, 2003, 91-94.

[15] B.J. Akinyele, Mcroorganisms Associated With Some Locally Processed Milk Products, Journal of Techno Science, 4, 2000, 28-30.

[16] I. Ismail, The Fulani Milk Maid and Problems of Dairying in Nigeria, African commune, 2004.

[17] R.M. Goodman, Expanding The Use of Soyabeans: Proceedings of a Conference For Asia and Oceanic, held in Chiang Mai, Thailand (International Soyabeans Programme Series, No. 10. February, 1976).

[18] J.J. Asiedu, Tropical Crops: A technological, Approach (Houndmills: Macmillan Education Ltd. 1990).

[19] O.H. Habeeb, Genotype and Environmental Interaction for Yield in Field Soyabean, Philippines Journals of Crop Science, 8, 1998, 3-9. 